\title{
Effect of paddy straw plus nonforage fiber sources based complete rations with different levels of neutral detergent fiber on hemato-biochemical and mineral profile of lactating dairy cows
}

\author{
Biju Chacko ${ }^{1}$, K. M. Syam Mohan ${ }^{1}$, K. Ally ${ }^{1}$, K. Shyama ${ }^{1}$, K. S. Anil ${ }^{2}$ and C. T. Sathian ${ }^{3}$ \\ 1. Department of Animal Nutrition, College of Veterinary and Animal Sciences, Mannuthy - 680651 , Thrissur, Kerala, \\ India; 2. University Livestock Farm \& Fodder Research and Development Scheme, Mannuthy - 680 651, Thrissur, Kerala, \\ India; 3. Department of Dairy Science, College of Veterinary and Animal Sciences, Mannuthy - 680 651, Thrissur, \\ Kerala, India. \\ Corresponding author: Biju Chacko, e-mail: bijuchacko@kvasu.ac.in \\ Co-authors: KMSM: shyam@kvasu.ac.in, KA: ally@kvasu.ac.in, KS: shyama@kvasu.ac.in, \\ KSA: anilks@kvasu.ac.in, CTS: ctsathian@gmail.com \\ Received: 28-12-2016, Accepted: 20-06-2017, Published online: 31-07-2017 \\ doi: 10.14202/vetworld.2017.836-842 How to cite this article: Chacko B, Mohan KMS, Ally K, Shyama K, Anil KS, Sathian \\ CT (2017) Effect of paddy straw plus nonforage fiber sources based complete rations with different levels of neutral \\ detergent fiber on hemato-biochemical and mineral profile of lactating dairy cows, Veterinary World, 10(7): 836-842.
}

\begin{abstract}
Aim: This study was conducted to assess the effect of feeding paddy straw plus nonforage fiber sources based complete rations with different levels of neutral detergent fiber (NDF) on hemato-biochemical and mineral parameters of lactating dairy cows.

Materials and Methods: The study was conducted for 6 months in 18 lactating dairy cows, divided into three groups of six each, by feeding them on paddy straw plus nonforage fiber sources based complete rations containing different levels of NDF, in two phases of 3 months (90 days) each, being the early and mid lactation phases, respectively. Three isonitrogenous and isocaloric complete rations, T1, T2 and T3 with 25\%, 30\% and 35\% NDF, respectively, were fed to the experimental animals. Blood samples were collected at the beginning and the end of each of the two phases to estimate the different hematological, plasma protein, and mineral parameters to know the overall health status of the animals and standard methods were followed to analyze the samples.
\end{abstract}

Results: There was no significant difference $(\mathrm{p}>0.05)$ in various hematological parameters such as hemoglobin, glucose, and blood urea nitrogen (BUN) in blood; plasma protein parameters such as total protein, albumin, globulin and albumin: globulin ratio and mineral parameters such as plasma calcium and phosphorus levels at the beginning and end of Phase I $\left(1^{\text {st }}\right.$ day and $90^{\text {th }}$ day) and Phase II ( $91^{\text {st }}$ day and $180^{\text {th }}$ day) as well as between the three dietary treatments, with all the values being in the normal range for lactating dairy cows. Even though nonsignificant ( $p>0.05)$, the BUN values of animals fed on ration T1, both at the beginning and end of Phase I, were higher than that of animals fed on rations T2 and T3 because the diet T1 with lowest NDF and the highest soluble carbohydrate content underwent rapid fermentation in the rumen, produced more energy, which was utilized by the rumen microbes to degrade the protein in the feed to ammonia, the excess ammonia being transported to the liver and excreted through the blood resulting in a higher BUN content.

Conclusion: Feeding of paddy straw plus nonforage fiber sources based complete rations with different levels of NDF had no effect on hemato-biochemical and mineral profile as well as overall health status of lactating dairy cows. However, the higher, BUN values found in cows fed on diet T1 with $25 \%$ NDF as compared to those fed on T2 and T3 with $30 \%$ and $35 \%$ NDF, respectively, indicate more wastage of protein in $\mathrm{T} 1$ as compared to $\mathrm{T} 2$ and $\mathrm{T} 3$, in early lactation.

Keywords: blood urea nitrogen, complete feeds, cows, hematology, neutral detergent fiber, paddy straw, plasma.

\section{Introduction}

Energy requirements of lactating dairy cows are met from the fibrous and nonfibrous carbohydrate fractions of the diet. To achieve maximum production, dairy rations should be balanced in neutral detergent fiber (NDF), i.e., the useful fiber, at the same time not compromising on the nonfibrous carbohydrate fractions so that optimum energy intake and rumen health

Copyright: Chacko, et al. Open Access. This article is distributed under the terms of the Creative Commons Attribution 4.0 International License (http://creativecommons.org/licenses/ by/4.0/), which permits unrestricted use, distribution, and reproduction in any medium, provided you give appropriate credit to the original author(s) and the source, provide a link to the Creative Commons license, and indicate if changes were made. The Creative Commons Public Domain Dedication waiver (http:// creativecommons.org/publicdomain/zero/1.0/) applies to the data made available in this article, unless otherwise stated. are ensured. The National Research Council of USA has recommended that a milking cow should be fed with a ration containing at least $25-33 \%$ of fiber in the form of NDF [1].

However, providing even this minimum quantity of fiber, from forage sources alone, is very difficult because, currently in India, green fodder is deficit to the tune of $56.73 \%$ [2]. This scarcity of green fodder could only be met in a sustained manner through the efficient use of crop residues that do not compete with human food.

Paddy and wheat straws are the principal crop residues which are used as fiber sources for ruminants in India. In the Northern states of India, wheat straw was preferred for feeding of livestock while most of the paddy straw was burnt. The need of the time was 
to blend straws along with locally available agro-industrial by products like brans which are nonforage fiber sources and also good sources of NDF. Once the NDF requirement is met in this manner, other concentrate ingredients can be added to it to form a complete feed or complete diet [3], which is a feasible and practical feeding practice that can be adopted. Among the various roughages such as grasses and straws, straw has got the highest rate of chewing and hence is most effective when added to complete feeds [4]. Paddy straw can be used as the sole source of forage NDF in complete rations for cows [5].

However, the optimum level of NDF in complete feeds, required to obtain maximum milk production, at the same time not compromising on its overall general health, needs to be studied. Most of the researches done on complete feeds in the western countries are grass based. In India, not much research has been conducted for formulating a paddy straw based complete feed with the optimum NDF level for lactating dairy cows.

Various hematological, plasma protein, and mineral parameters are very good indices of the overall health status of cows, in various stages of lactation [6]. However, literature available on hemato-biochemical parameters of lactating dairy cows, fed on complete rations with different levels of NDF, is scanty. Hence, this study was conducted to assess the overall health status of cows fed on paddy straw plus nonforage fiber sources based complete rations having different levels of NDF, by estimating the different hematological, plasma protein, and mineral parameters, in both early and mid lactation.

\section{Materials and Methods}

\section{Ethical approval}

The present study is a part of the Ph.D project (Code No. CB/1/9/DVM/2012/AN) entitled, "evaluation of complete feeds with varying levels of neutral detergent fiber for lactating dairy cows" of Dr. Biju Chacko, the first author and ethical approval for the same was provided in the $2^{\text {nd }}$ meeting of the Faculty Research Council of the Kerala Veterinary and Animal Sciences University, held at College of Veterinary and Animal Sciences, Mannuthy on 18-52013 as per Order No. DAR/Acad(2)/1769/2013(12) dt. 22-7-2013 of the Director of Academics \& Research, Kerala Veterinary and Animal Sciences University, Pookode.

\section{Experimental design, management and laboratory analysis}

A total of 18 crossbred dairy cows in the early stage of lactation (within 2 weeks of calving) were selected from the University Livestock Farm and Fodder Research and Development Scheme, Mannuthy. They were divided into three groups of six each, as uniformly as possible with regard to age, parity, milk yield, and body weight and were allotted randomly in a completely randomized design to three complete rations, $\mathrm{T} 1, \mathrm{~T} 2$ and $\mathrm{T} 3$, formulated as per the recommendations of ICAR feeding standards [7]. All the cows were maintained under uniform management conditions prevailing in the farm, the average maximum and minimum temperatures being $33^{\circ} \mathrm{C}$ and $28^{\circ} \mathrm{C}$, respectively. All the animals were dewormed with Albendazole $2.5 \%$ suspension orally, before the start of the trial. Scheduled vaccinations such as foot and mouth disease and hemorrhagic septicemia as well as standard managerial practices were followed during the experiment. The experiment was conducted from September to February.

The cows were housed individually in a well-ventilated shed with cemented floor. The animals in the three dietary treatments, T1, T2 and T3, were fed with complete rations containing different levels of NDF, viz., $25 \%, 30 \%$ and $35 \%$, respectively. The rations were made isonitrogenous $(12.00-13.00 \%$ crude protein) and isocaloric (63-65\% total digestible nutrients) and were compared on the basis of feeding trials of total 180 days duration, in two phases of 3 months each, the first 90 days being the early lactation and the next 90 days being the mid lactation. The ingredient composition and the calculated nutrient content of the experimental rations in the two phases are depicted in Tables-1 and 2, respectively.

Weighed quantities of complete feed were fed individually, on an ad libitum basis, to all the animals and the balance feed in the manger was collected manually and weighed, twice a day, in the morning and afternoon at $9 \mathrm{AM}$ and $2 \mathrm{PM}$, respectively. Ad libitum drinking water was provided to the cows using automatic watering system. Proximate principles of feed were determined as per standard procedure of AOAC [8]. The acid detergent fiber and NDF were estimated by the detergent method of analysis [9]. The calcium and phosphorus contents of the feed were analyzed as per the standard procedure described in AOAC [8].

Table-1: Ingredient composition of experimental complete feeds offered to cows in Phases I and II, kg.

\begin{tabular}{lcccccccc}
\hline \multirow{2}{*}{ Ingredient } & \multicolumn{3}{c}{ Phase I } & & \multicolumn{3}{c}{ Phase II } \\
\cline { 2 - 4 } \cline { 7 - 8 } & T1 & T2 & T3 & & T1 & T2 & T3 \\
\hline Maize & 37 & 27 & 16 & & 38 & 30 & 21 \\
Coconut cake & 11 & 12 & 17 & & 5 & 8 & 12 \\
(de-oiled) & & & & & & \\
Rape seed meal & 11 & 12 & 11 & & 10 & 10 & 10 \\
De-oiled rice bran & 20 & 19 & 16.50 & 26 & 23 & 21 \\
Paddy straw & 14 & 21 & 29 & & 14 & 22 & 29 \\
Molasses & 5 & 5 & 5 & 5 & 5 & 5 \\
Calcite & 1.50 & 1.50 & 1.50 & 1.5 & 1.5 & 1.5 \\
Salt & 0.50 & 0.50 & 0.50 & 0.5 & 0.5 & 0.5 \\
Vegetable fat & - & 2.00 & 3.50 & - & - & - \\
Total & $100 *$ & $100 *$ & $100 *$ & $100 *$ & $100 *$ & $100 *$ \\
\hline
\end{tabular}

*To every $1 \mathrm{~kg}$ of complete feed, $0.10 \mathrm{~g}$ of vitamin $\mathrm{AD}_{3} \mathrm{E}$ supplement (containing 10,000 IU of vitamin A, $2000 \mathrm{IU}$ of vitamin $\mathrm{D}_{3}$ and $1000 \mathrm{IU}$ of vitamin $\left.\mathrm{E}\right), 0.50 \mathrm{~g}$ of trace mineral mixture (Keramin Forte) and $0.50 \mathrm{~g}$ of toxin binder (Curatox) were added 
Table-2: Chemical composition of complete offered to cows in Phases I and II (\% DM basis).

\begin{tabular}{|c|c|c|c|c|c|c|}
\hline \multirow[t]{2}{*}{ Nutrient } & \multicolumn{3}{|c|}{ Phase I } & \multicolumn{3}{|c|}{ Phase II } \\
\hline & T1 & $\mathbf{T 2}$ & T3 & T1 & T2 & T3 \\
\hline CP & 12.23 & 12.94 & 12.18 & 12.40 & 12.14 & 12.08 \\
\hline Crude fiber & 10.73 & 12.68 & 15.01 & 10.53 & 12.70 & 14.85 \\
\hline Ether extract & 4.00 & 3.60 & 3.80 & 4.50 & 3.50 & 3.60 \\
\hline Total ash & 14.00 & 12.90 & 12.90 & 14.10 & 13.30 & 12.98 \\
\hline $\begin{array}{l}\text { Nitrogen free } \\
\text { extract }\end{array}$ & 59.04 & 57.88 & 56.11 & 58.47 & 58.36 & 56.49 \\
\hline Acid insoluble ash & 5.30 & 5.60 & 6.00 & 4.80 & 5.40 & 6.20 \\
\hline NDF & 25.88 & 30.03 & 35.59 & 25.94 & 30.86 & 35.38 \\
\hline ADF & 21.60 & 23.10 & 24.80 & 21.80 & 23.00 & 25.01 \\
\hline Calcium & 0.83 & 0.85 & 0.87 & 0.81 & 0.84 & 0.86 \\
\hline Phosphorus & 0.54 & 0.52 & 0.48 & 0.59 & 0.55 & 0.52 \\
\hline TDN* & 64.50 & 64.44 & 64.28 & 64.04 & 63.28 & 63.25 \\
\hline $\begin{array}{l}\text { Metabolisable } \\
\text { energy* } \\
\text { (MJ/kg DM) }\end{array}$ & 9.00 & 8.87 & 8.41 & 9.04 & 8.54 & 8.24 \\
\hline
\end{tabular}

*Calculated value. ADF=Acid detergent fiber, $\mathrm{NDF}=$ Neutral detergent fiber, $\mathrm{TDN}=$ Total digestible nutrients, $\mathrm{CP}=$ Crude protein, $\mathrm{DM}=$ Dry matter

\section{Estimation of hemato-biochemical and mineral parameters}

Blood samples (15 ml each) were collected aseptically by puncturing the jugular vein using 18 gauge disposable needle into two sets of sterilized vials, one without anticoagulant and the other with anticoagulant ( $1^{\text {st }}$ day), at the end of Phase I $\left(90^{\text {th }}\right.$ day) and at the end of the experiment $\left(180^{\text {th }}\right.$ day), before the morning feeding. Blood samples with ethylenediaminetetraacetic acid were used immediately for estimation of hemoglobin (cyanmethemoglobin method) using the standard kits supplied by Agappe Diagnostics, Maharashtra, India.

Blood without anticoagulant was allowed to clot; the plasma was separated in a fresh vial and stored at $-20^{\circ} \mathrm{C}$ for the analysis of blood glucose (glycerol-3-phosphate oxidase-phenol + aminophenazone method), blood urea nitrogen (BUN) (modified Berthelot method), total protein (direct Biuret method), albumin (bromocresol green methodology), calcium (modified o-cresolphthalein complexone method), and inorganic phosphorus (phosphomolybdate method) using the standard kits supplied by Agappe Diagnostics to assess the overall health status of cows fed on paddy straw plus nonforage fiber sources based complete rations having different levels of NDF. All the hematological, plasma protein, and mineral parameters listed above were determined using the Autoanalyzer (Mispa plus, SEAC radium group). Plasma globulin was calculated by subtracting albumin from total protein and albumin: globulin ratio was calculated using the formula: Albumin $\div$ globulin.

\section{Statistical analysis}

Data gathered on the various parameters were analyzed statistically using single factor analysis of variance technique [10], using the software, statistical product and service solutions (SPSS) version 21.0 [11]. Homogenous subsets were separated using Duncan's multiple range test, described by Duncan [12]. Differences among treatments were considered to be significant, when $\mathrm{p} \leq 0.05$.

\section{Results}

In this study different hematological, plasma protein and mineral parameters, in both early and mid lactation, were observed.

\section{Hematological parameters}

The data on the values of blood parameters such as hemoglobin, glucose, and BUN of blood samples collected from the experimental animals in Phases I and II of the experiment are given in Table-3.

The average hemoglobin levels in animals fed on the three experimental rations $\mathrm{T} 1, \mathrm{~T} 2$ and $\mathrm{T} 3$, at the beginning of the experiment ( $1^{\text {st }}$ day) were $10.45 \pm 0.50$, $10.76 \pm 0.72$ and $10.78 \pm 0.87 \mathrm{~g} / 100 \mathrm{ml}$, respectively. The values at the end of Phase I ( $90^{\text {th }}$ day) were $9.72 \pm 0.37$, $10.53 \pm 0.52$ and $10.49 \pm 0.76 \mathrm{~g} / 100 \mathrm{ml}$, respectively, for animals fed on T1, T2 and T3, and the values at the end of Phase II $\left(180^{\text {th }}\right.$ day) were $9.89 \pm 0.39,11.31 \pm 0.60$ and $11.20 \pm 0.86 \mathrm{~g} / 100 \mathrm{ml}$, respectively, for cows fed on T1, T2 and T3. The above data revealed that there was no significant difference $(\mathrm{p}>0.05)$ in hemoglobin values between the three dietary treatments, throughout Phases I and II and the values were in the normal range for cows.

The initial values ( $1^{\text {st }}$ day) of average blood glucose levels of animals fed on the three experimental rations, T1, T2 and $\mathrm{T} 3$ were $67.07 \pm 1.57,66.19 \pm 1.23$ and $66.54 \pm 0.62 \mathrm{mg} / 100 \mathrm{ml}$, respectively. The values at the end of Phase I ( $90^{\text {th }}$ day) were $62.44 \pm 0.91$, $63.65 \pm 1.23$ and $62.60 \pm 0.58 \mathrm{mg} / 100 \mathrm{ml}$ for the animals in T1, T2 and T3, respectively, and the values at the end of Phase II (180 ${ }^{\text {th }}$ day) were $66.11 \pm 1.09,66.10 \pm 0.78$ and $65.94 \pm 0.50 \mathrm{mg} / 100 \mathrm{ml}$, respectively, for cows fed on T1, T2 and T3. The above data revealed that there was no significant difference $(p>0.05)$ in blood glucose levels of cows fed on the three experimental rations, throughout Phase I and Phase II and the values were in the normal range for lactating cows.

The BUN concentration of animals fed on the three experimental rations; T1, T2 and T3 were $14.05 \pm 1.09,12.97 \pm 0.33$ and $12.95 \pm 0.52 \mathrm{mg} / 100 \mathrm{ml}$, respectively, at the start of the experiment ( $1^{\text {st }}$ day). The BUN values at the end of Phase I $\left(90^{\text {th }}\right.$ day $)$ were $11.23 \pm 1.25,9.64 \pm 0.49$ and $9.86 \pm 0.51 \mathrm{mg} / 100 \mathrm{ml}$, respectively, for the animals fed on the three experimental rations, T1, T2 and T3. The BUN values at the end of Phase II $\left(180^{\text {th }}\right.$ day) were $7.82 \pm 0.45,8.49 \pm 0.24$ and $8.64 \pm 0.31 \mathrm{mg} / 100 \mathrm{ml}$, respectively, for the animals fed on T1, T2 and T3. The above data indicate that there was no significant difference $(p>0.05)$ in BUN values between the three dietary treatments, throughout Phases I and II and the values were in the normal range for lactating cows.

\section{Plasma protein parameters}

The data on values of plasma protein parameters such as total protein, albumin, globulin and 
Table-3: Blood*, plasma protein* and mineral parameters* of animals maintained on the three experimental rations in Phases I and II.

\begin{tabular}{|c|c|c|c|c|c|}
\hline \multirow[t]{2}{*}{ Parameter } & \multirow[t]{2}{*}{ Day } & \multicolumn{3}{|c|}{ Treatment } & \multirow[t]{2}{*}{ p value } \\
\hline & & T1 & T2 & T3 & \\
\hline \multirow[t]{3}{*}{ Hemoglobin (g/100 ml) } & 1 & $10.45 \pm 0.50$ & $10.76 \pm 0.72$ & $10.78 \pm 0.87$ & 0.934 \\
\hline & 90 & $9.72 \pm 0.37$ & $10.53 \pm 0.52$ & $10.49 \pm 0.76$ & 0.543 \\
\hline & 180 & $9.89 \pm 0.39$ & $11.31 \pm 0.60$ & $11.20 \pm 0.86$ & 0.253 \\
\hline \multirow[t]{3}{*}{ Blood glucose $(\mathrm{mg} / 100 \mathrm{ml})$} & 1 & $67.07 \pm 1.57$ & $66.19 \pm 1.23$ & $66.54 \pm 0.62$ & 0.874 \\
\hline & 90 & $62.44 \pm 0.91$ & $63.65 \pm 1.23$ & $62.60 \pm 0.58$ & 0.625 \\
\hline & 180 & $66.11 \pm 1.09$ & $66.10 \pm 0.78$ & $65.94 \pm 0.50$ & 0.987 \\
\hline \multirow[t]{3}{*}{ BUN (mg/100 ml) } & 1 & $14.05 \pm 1.09$ & $12.97 \pm 0.33$ & $12.95 \pm 0.52$ & 0.486 \\
\hline & 90 & $11.23 \pm 1.25$ & $9.64 \pm 0.49$ & $9.86 \pm 0.51$ & 0.366 \\
\hline & 180 & $7.82 \pm 0.45$ & $8.49 \pm 0.24$ & $8.64 \pm 0.31$ & 0.230 \\
\hline \multirow[t]{3}{*}{ Total protein $(\mathrm{g} / 100 \mathrm{ml})$} & 1 & $7.31 \pm 0.33$ & $7.47 \pm 0.16$ & $7.17 \pm 0.3$ & 0.749 \\
\hline & 90 & $7.06 \pm 0.35$ & $7.00 \pm 0.12$ & $7.14 \pm 0.33$ & 0.941 \\
\hline & 180 & $7.38 \pm 0.34$ & $7.52 \pm 0.15$ & $7.58 \pm 0.24$ & 0.845 \\
\hline \multirow[t]{3}{*}{ Albumin (g/100 ml) } & 1 & $4.18 \pm 0.14$ & $4.17 \pm 0.09$ & $4.17 \pm 0.2$ & 0.998 \\
\hline & 90 & $3.96 \pm 0.20$ & $3.95 \pm 0.17$ & $3.94 \pm 0.24$ & 0.996 \\
\hline & 180 & $4.26 \pm 0.18$ & $4.27 \pm 0.20$ & $4.24 \pm 0.19$ & 0.992 \\
\hline \multirow[t]{3}{*}{ Globulin (g/100 ml) } & 1 & $3.13 \pm 0.22$ & $3.31 \pm 0.08$ & $3.00 \pm 0.19$ & 0.487 \\
\hline & 90 & $3.10 \pm 0.15$ & $3.05 \pm 0.06$ & $3.21 \pm 0.21$ & 0.762 \\
\hline & 180 & $3.12 \pm 0.16$ & $3.25 \pm 0.32$ & $3.35 \pm 0.12$ & 0.764 \\
\hline \multirow[t]{3}{*}{ Albumin: globulin ratio } & 1 & $1.36 \pm 0.09$ & $1.26 \pm 0.02$ & $1.41 \pm 0.11$ & 0.433 \\
\hline & 90 & $1.28 \pm 0.01$ & $1.30 \pm 0.08$ & $1.25 \pm 0.11$ & 0.902 \\
\hline & 180 & $1.37 \pm 0.02$ & $1.41 \pm 0.20$ & $1.27 \pm 0.07$ & 0.726 \\
\hline \multirow[t]{3}{*}{ Plasma Ca (mg/100 ml) } & 1 & $9.11 \pm 0.49$ & $9.33 \pm 0.49$ & $8.83 \pm 0.46$ & 0.766 \\
\hline & 90 & $8.23 \pm 0.07$ & $8.41 \pm 0.33$ & $8.15 \pm 0.25$ & 0.754 \\
\hline & 180 & $9.68 \pm 0.46$ & $9.87 \pm 0.76$ & $9.43 \pm 0.24$ & 0.848 \\
\hline \multirow[t]{3}{*}{ Plasma P (mg/100 ml) } & 1 & $4.41 \pm 0.07$ & $4.83 \pm 0.21$ & $4.72 \pm 0.17$ & 0.199 \\
\hline & 90 & $5.03 \pm 0.13$ & $5.23 \pm 0.25$ & $5.26 \pm 0.32$ & 0.772 \\
\hline & 180 & $5.37 \pm 0.20$ & $5.47 \pm 0.33$ & $5.69 \pm 0.29$ & 0.711 \\
\hline
\end{tabular}

*Average of six values. BUN=Blood urea nitrogen

albumin:globulin ratio, in Phases I and II are depicted in Table-3.

The average total protein content in animals fed on the three experimental rations T1, T2 and T3; at the beginning of the experiment ( $1^{\text {st }}$ day) were $7.31 \pm 0.33$, $7.47 \pm 0.16$ and $7.17 \pm 0.30 \mathrm{~g} / 100 \mathrm{ml}$, respectively. The values at the end of Phase I ( $90^{\text {th }}$ day) were $7.06 \pm 0.35$, $7.00 \pm 0.12$ and $7.14 \pm 0.33 \mathrm{~g} / 100 \mathrm{ml}$, respectively, for the animals fed on T1, T2 and T3 and the values at the end of Phase II ( $180^{\text {th }}$ day) were $7.38 \pm 0.34,7.52 \pm 0.15$ and $7.58 \pm 0.24 \mathrm{~g} / 100 \mathrm{ml}$, respectively, for the animals fed on T1, T2 and T3. The above data revealed that there was no significant difference $(p>0.05)$ in total protein levels between the three dietary treatments, throughout Phase I and Phase II and the values were in the normal range for cows.

The average albumin content in animals fed on the three experimental rations T1, T2 and T3, at the beginning of the experiment $\left(1^{\text {st }}\right.$ day) were $4.18 \pm 0.14,4.17 \pm 0.09$ and $4.17 \pm 0.20 \mathrm{~g} / 100 \mathrm{ml}$, respectively. The values at the end of Phase I $\left(90^{\text {th }}\right.$ day) were $3.96 \pm 0.20,3.95 \pm 0.17$ and $3.94 \pm 0.24 \mathrm{~g} / 100 \mathrm{ml}$, respectively, for the animals fed on T1, T2 and T3, and the values at the end of Phase II $\left(180^{\text {th }}\right.$ day) were $4.26 \pm 0.18,4.27 \pm 0.20$ and $4.24 \pm 0.19 \mathrm{~g} / 100 \mathrm{ml}$, respectively, for cows fed on $\mathrm{T} 1, \mathrm{~T} 2$ and $\mathrm{T} 3$. The above data revealed that there was no significant difference $(p>0.05)$ in albumin levels between the three dietary treatments, throughout Phase I and Phase II and the values were in the normal range for cows.

The average globulin content in animals fed on the three experimental rations $\mathrm{T} 1, \mathrm{~T} 2$ and $\mathrm{T} 3$, at the beginning of the experiment ( $\left(1^{\text {st }}\right.$ day) was $3.13 \pm 0.22$, $3.31 \pm 0.08$ and $3.00 \pm 0.19 \mathrm{~g} / 100 \mathrm{ml}$, respectively. The values at the end of Phase I ( $90^{\text {th }}$ day) were $3.10 \pm 0.15$, $3.05 \pm 0.06$ and $3.21 \pm 0.21 \mathrm{~g} / 100 \mathrm{ml}$, respectively, for the animals fed on T1, T2 and T3 and the values at the end of Phase II ( $\left(180^{\text {th }}\right.$ day) were $3.12 \pm 0.16,3.25 \pm 0.32$ and $3.35 \pm 0.12 \mathrm{~g} / 100 \mathrm{ml}$, respectively, for cows fed on T1, T2 and T3. The above data revealed that there was no significant difference $(p>0.05)$ in globulin levels between the three dietary treatments, throughout Phases I and II and the values were in the normal range for cows.

The albumin:globulin ratio in animals fed on the three experimental rations $\mathrm{T} 1, \mathrm{~T} 2$ and $\mathrm{T} 3$, at the beginning of the experiment ( $1^{\text {st }}$ day) was $1.36 \pm 0.09$, $1.26 \pm 0.02$ and $1.41 \pm 0.11$, respectively. The values at the end of Phase I ( $90^{\text {th }}$ day) was $1.28 \pm 0.01,1.30$ \pm 0.08 and $1.25 \pm 0.11$, respectively, for the animals fed on T1, T2 and T3 and the values at the end of Phase II $\left(180^{\text {th }}\right.$ day) were $1.37 \pm 0.02,1.41 \pm 0.20$ and $1.27 \pm 0.07$, respectively, for cows fed on T1, T2 and T3. The above data revealed that there was no significant difference $(p>0.05)$ in albumin: Globulin ratio between the three dietary treatments, throughout Phases I and II and the values were within the normal range for cattle. 


\section{Mineral parameters}

The data on values of mineral parameters such as plasma calcium and phosphorus, in Phase I and II are depicted in Table-3.

The plasma calcium content in animals fed on the three experimental rations $\mathrm{T} 1, \mathrm{~T} 2$ and $\mathrm{T} 3$, at the beginning of the experiment ( $1^{\text {st }}$ day) was $9.11 \pm 0.49$, $9.33 \pm 0.49$ and $8.83 \pm 0.46 \mathrm{mg} / 100 \mathrm{ml}$, respectively. The values at the end of Phase I ( $90^{\text {th }}$ day) were $8.23 \pm 0.07$, $8.41 \pm 0.33$ and $8.15 \pm 0.25 \mathrm{mg} / 100 \mathrm{ml}$, respectively, for cows fed on T1, T2 and T3 and the values at the end of Phase II $\left(180^{\text {th }}\right.$ day $)$ were $9.68 \pm 0.46,9.87 \pm 0.76$ and $9.43 \pm 0.24 \mathrm{mg} / 100 \mathrm{ml}$, respectively, for those fed on $\mathrm{T} 1, \mathrm{~T} 2$ and T3. The above data revealed that there was no significant difference $(p>0.05)$ in plasma calcium content between the three dietary treatments, throughout Phase I and the values were within the normal range for dairy cows.

The plasma phosphorus content in animals fed on the three experimental rations $\mathrm{T} 1, \mathrm{~T} 2$ and $\mathrm{T} 3$, at the beginning of the experiment ( $1^{\text {st }}$ day) were $4.41 \pm 0.07$, $4.83 \pm 0.21$ and $4.72 \pm 0.17 \mathrm{mg} / 100 \mathrm{ml}$, respectively. The values at the end of Phase I ( $90^{\text {th }}$ day) were $5.03 \pm 0.13$, $5.23 \pm 0.25$ and $5.26 \pm 0.32 \mathrm{mg} / 100 \mathrm{ml}$, respectively, for the animals fed on T1, T2 and T3. The values at the end of Phase II were $5.37 \pm 0.20,5.47 \pm 0.33$ and $5.69 \pm 0.29 \mathrm{mg} / 100 \mathrm{ml}$, respectively, for the cows fed on T1, T2 and T3. The above data revealed that there was no significant difference $(p>0.05)$ in plasma phosphorus content between the three dietary treatments, throughout Phase I and the values were within the normal range for dairy cows.

\section{Discussion}

\section{Hematological parameters}

The hemoglobin values obtained in Phases I and II of the present study are comparable to those of Ally [13] who reported values in the range of $8.35-10.70 \mathrm{~g} / 100 \mathrm{ml}$ in early lactation and 9.80$11.00 \mathrm{~g} / 100 \mathrm{ml}$ in mid-lactation dairy cows fed on conventional paddy straw-concentrate rations where the NDF content of the total ration was in the range of $30.72-34.76 \%$ and $38.65-39.40 \%$ in early and mid-lactation, respectively. The values obtained in the present study are also comparable to the values of Mohan [14] who reported hemoglobin values in the range of 8.61$9.75 \mathrm{~g} / 100 \mathrm{ml}$ and $9.49-11.25 \mathrm{~g} / 100 \mathrm{ml}$, respectively, in dairy cows fed on conventional paddy straw-concentrate rations with total NDF content of $38.62 \%$ and $43.55 \%$, respectively, in the $3^{\text {rd }}$ and $6^{\text {th }}$ month of lactation. The values of the current study are higher than those reported by Mondal and Paul [15] who obtained hemoglobin values in the range of 9.13-9.64 g/100 ml in lactating multiparous dairy cows.

The blood glucose values obtained in Phases I and II of the present study are higher than those reported by Ally [13] who reported plasma glucose values in the range of $51-62 \mathrm{mg} / 100 \mathrm{ml}$ early lactation and $43.57-62.14 \mathrm{mg} / 100 \mathrm{ml}$ in mid-lactation dairy cows fed on conventional paddy straw-concentrate rations; Delahoy et al. [16] who reported blood glucose content of 69.20 and $68.50 \mathrm{mg} / 100 \mathrm{ml}$, respectively, in cows fed on complete rations containing cracked and steam flaked corn; Hundal et al. [17] who reported values in the range of $54.46-54.98 \mathrm{mg} / 100 \mathrm{ml}$ in lactating cows fed on total mixed rations (TMRs); Shiraz et al. [18] who got plasma glucose values in the range of 56.56-64.58 mg/100 $\mathrm{ml}$ in crossbred cows fed on wheat straw based TMRs; Mondal and Paul [15] who got blood glucose values in the range of 42.40$49.20 \mathrm{mg} / 100 \mathrm{ml}$, in lactating multiparous dairy cows and Shakkarpude et al. [19] who obtained values in the range of $61.33-64.50 \mathrm{mg} / 100 \mathrm{ml}$ in lactating crossbred dairy cows. The values obtained in are in the present study are lower than the values of Kim et al. [20] who reported that the blood glucose content of Hanwoo steers fed on TMRs with and without fermented feed were in the range of $86.50-91.50 \mathrm{mg} / 100 \mathrm{ml}$.

The BUN values observed in the present study are comparable to those reported by Hundal et al. [17] who observed that crossbred milking cows fed on a TMR had a BUN value of $13.00 \mathrm{mg} / 100 \mathrm{ml}$. The BUN values of the present investigation are also comparable to those of Kim et al. [20] who reported that the BUN content of Hanwoo steers fed on TMRs, with and without fermented feed, ranged from 9.82 to $13.30 \mathrm{mg} / 100 \mathrm{ml}$. The values obtained in Phases I and II of the present study are lower than those reported by Ally [13] who reported BUN values in the range of $13.60-21.50 \mathrm{mg} / 100 \mathrm{ml}$ in early lactation and $35.30-44.40 \mathrm{mg} / 100 \mathrm{ml}$ in mid-lactation dairy cows fed on conventional paddy straw-concentrate rations; Delahoy et al. [16] who obtained plasma urea nitrogen values of 12.50 and $13.70 \mathrm{mg} / 100 \mathrm{ml}$ in lactating dairy cows fed on complete rations containing steam-flaked and cracked corn, respectively and Pina et al. [21] who reported that the urea nitrogen concentration of serum in lactating Holstein cows fed on complete diets consisting of four different protein sources were in the range of $18.24-22.97 \mathrm{mg} / 100 \mathrm{ml}$.

Perusal of the data on BUN of the experimental animals fed on the three experimental rations, given in Table-3 revealed that the BUN values of animals in T1, both at the beginning and end of Phase I, were higher than that of animals in T2 and T3, even though the increases were non-significant $(\mathrm{p}>0.05)$. The higher BUN values observed in T1 was because the diet T1 with lowest NDF and the highest soluble carbohydrate content underwent rapid fermentation in the rumen, and the resultant energy produced was utilized by the rumen microbes to degrade the protein in the feed to ammonia which in turn resulted in an increase in rumen ammonia. The excess ammonia produced was transported to the liver and excreted through the blood which resulted in a higher BUN content in T1 than T2 and T3, which indicated more wastage of protein in $\mathrm{T} 1$ as compared to $\mathrm{T} 2$ and $\mathrm{T} 3$, in early lactation. 


\section{Plasma protein parameters}

The values of total protein obtained in this study are comparable to those of Shakkarpude et al. [19] who got values in the range of 7.25-7.97 g/100 ml in lactating crossbred dairy cows. The values observed in the present study are higher than those of Shiraz et al. [18] who reported plasma total protein values in the range of 6.62-6.97 $\mathrm{g} / 100 \mathrm{ml}$ in crossbred milch cows in early lactation, fed on wheat straw based TMRs. The values are also higher than those observed by Kim et al. [20] who reported that the total protein content of Hanwoo steers fed on a TMR with and without fermented feed were in the range of 6.11-6.28 g/100 ml, and Mondal and Paul [15] who reported plasma total protein values in the range of 6.62-6.97 g/100 $\mathrm{ml}$ in lactating multiparous dairy cows. The values obtained in this experiment are lower than that reported by Hundal et al. [17] who reported that the total protein content in crossbred milking cows fed on a TMR was $9.08 \mathrm{~g} / 100 \mathrm{ml}$.

The values of albumin obtained in this study are comparable to those reported by Hundal et al. [17] who observed that the albumin content in plasma of crossbred milking cows fed on a TMR was 3.52 and $4.76 \mathrm{~g} / 100 \mathrm{ml}$. The values of albumin observed in the present study are higher than those of Shiraz et al. [18] who reported plasma albumin values in the range of 2.95-3.18 g/100 $\mathrm{ml}$ in crossbred milch cows fed on wheat straw-based TMRs; Kim et al. [20] who reported that the total protein content of Hanwoo steers fed on a TMR with and without fermented feed was in the range of 3.65-3.89 g/100 ml and Mondal and Paul [15] who reported plasma albumin values in the range of $2.71-2.77 \mathrm{~g} / 100 \mathrm{ml}$ in lactating multiparous dairy cows.

The values of globulin reported in the present study are higher than those observed by Mondal and Paul [15] who reported plasma globulin values in the range of 2.82-2.89 g/100 $\mathrm{ml}$ in lactating multiparous dairy cows. The values of globulin obtained in this study are lower than those reported by Hundal et al. [17] who observed that the globulin content in plasma of crossbred milking cows fed on a TMR was $5.57 \mathrm{~g} / 100 \mathrm{ml}$, and Shiraz et al. [18] who got plasma globulin values in the range of 3.58-3.82 g/100 $\mathrm{ml}$ in crossbred milch cows fed on wheat straw based TMRs.

The values of albumin:globulin ratio obtained in this study are comparable to those of Raghuvansi et al. [22] who reported an albumin:globulin ratio of 1.03-1.54 in Malpura rams fed on pearl millet stover based complete feeds and higher than those observed by Mondal and Paul [15] who reported values in the range of 0.96-0.98 in lactating multiparous dairy cows.

\section{Mineral parameters}

The values of plasma calcium observed in this study are comparable to those of Ally [13] who reported values ranging from 8.33 to $9.67 \mathrm{mg} / 100 \mathrm{ml}$ in a study conducted to assess the effect of varying levels of dietary protein as well as varying degradability of the protein in lactating dairy cows fed on conventional paddy straw-concentrate rations. The plasma calcium values of this study are also comparable to those observed by Cozzi et al. [23] who analyzed the blood samples of 740 Holstein cows collected from 33 Italian dairy herds and reported that the mean serum calcium was $9.62 \mathrm{mg} / 100 \mathrm{ml}$ and Dominic [24] who conducted a study to find out the effect of high energy diet in early lactation and reported values in the range of $9.01-9.91 \mathrm{mg} / 100 \mathrm{ml}$ in lactating dairy cows. The calcium values reported in this study are higher than those of Jacob [25] who got values ranging from 7.30 to $7.47 \mathrm{mg} / 100 \mathrm{ml}$ in a study conducted to assess the mineral status during pregnancy in crossbred cattle. The plasma calcium values of this study are lower than those of Mohan [14] who reported values ranging from 10.00 to $11.25 / 100 \mathrm{ml}$ in a study conducted to assess the effect of dietary level of minerals in lactating crossbred dairy cows.

The values of plasma phosphorus observed in the present study are comparable to those of Shakkarpude et al. [19] who conducted studies to assess the effect of plasma phosphorus on reproductive performance and reported inorganic phosphorus values in the range of $4.40-5.43 \mathrm{mg} / 100 \mathrm{ml}$ in lactating crossbred dairy cows. The values are also comparable to those of Dominic [24] who reported plasma phosphorus values in the range of $4.78-5.04 \mathrm{mg} / 100 \mathrm{ml}$ in lactating dairy cows. The values of plasma phosphorus observed in the present study were lower than those of Jacob [25] who reported plasma phosphorus values ranging from 6.02 to $6.20 \mathrm{mg} / 100 \mathrm{ml}$; Ally [13] who reported values ranging from 6.24 to $7.74 \mathrm{mg} / 100 \mathrm{ml}$; Mohan [14] who obtained values ranging from 6.01 to $6.40 \mathrm{mg} / 100 \mathrm{ml}$ in lactating crossbred cows and Cozzi et al. [23] who reported that the mean value of serum phosphorus was $6.57 \mathrm{mg} / 100 \mathrm{ml}$ in Holstein cows.

Normal blood levels of various biochemical constituents are indispensable for normal functioning of various systems of the body [26]. The normal values of all blood, plasma protein, and mineral parameters of cows fed on the three experimental rations, T1, T2 and T3, in Phases I and II, observed in the present study must have contributed to the overall health status of the animals in all the dietary treatments.

\section{Conclusion}

Feeding of paddy straw plus nonforage fiber sources based complete rations with different levels of NDF had no effect on hemato-biochemical and mineral profile as well as overall health status of lactating dairy cows. However, the higher, BUN values found in cows fed on diet T1 with $25 \% \mathrm{NDF}$ as compared to those fed on T2 and T3 with $30 \%$ and $35 \%$ NDF, respectively, indicate more wastage of protein in $\mathrm{T} 1$ as compared to $\mathrm{T} 2$ and $\mathrm{T} 3$, in early lactation. The results of the present investigation reveal that complete rations with $25-35 \%$ NDF, containing paddy straw 
as the sole source of roughage NDF, can be recommended for use among early and mid-lactation dairy cows, with $30 \%$ and $35 \%$ being the ideal NDF level.

\section{Authors' Contributions}

$\mathrm{BC}, \mathrm{KMSM}, \mathrm{KA}$, and $\mathrm{KS}$ designed all steps of the study. BC, KSA, and CTS collected samples of blood and evaluated throughout the study. BC and KMSM analyzed the data statistically. BC, KMSM, KA and $\mathrm{KS}$ prepared the tables of results and discussed it. BC wrote the manuscript draft and all authors have read, revised and approved the final draft.

\section{Acknowledgments}

The authors express their gratitude to the Kerala Veterinary and Animal Sciences University, Pookode, Wayanad, for providing the necessary fund and facilities required for the study. The requisite fund was granted as per Order No. KVASU/ DAR/Admn(2)/2260/2013 dt. 20-8-2013 of Director of Academics and Research, Kerala Veterinary and Animal Sciences, Pookode.

\section{Competing Interests}

The authors declare that they have no competing interests.

\section{References}

1. NRC. (2001) Nutrient Requirements for Dairy Cattle. $7^{\text {th }}$ ed. National Academy of Sciences, Washington, DC, USA. p408.

2. Datta, D. (2013) Indian fodder management towards 2030: A case of vision or Myopia. Int. J. Manag. Soc. Sci. Res., 2(2): 33-41.

3. Lailer, P.C., Dahiya, S.S. and Chauhan, T.R. (2005) Complete feed for livestock concept, present status and future trend: A review. Indian. J. Anim. Sci., 75(1): 84-91.

4. Stone, W.C. (2004) Nutritional approaches to minimize subacute ruminal acidosis and laminitis in dairy cattle. J. Dairy Sci., 87 E Suppl: 13-26.

5. Sadagopan, V.R. and Sunder, G.S. (1997) Quality control of feed ingredients and compounded feed for sustainable milk and egg production. In: Proceedings of VIII Animal Nutrition Research Workers Conference; $12^{\text {th }}$ to 14 $4^{\text {th }}$ December, 1997. Tamil Nadu Veterinary and Animal Sciences University, Chennai. p30-37.

6. Nozad, S., Ramin, A.G., Moghaddam, G., Asri, R.S. and Kalantary, L. (2014) Monthly evaluation of blood hematological, biochemical, mineral, and enzyme parameters during the lactation period in Holstein dairy cows. Comp. Clin. Pathol.,23(2): 275-281.

7. ICAR-NIANP. (2013) Nutrient Requirements of Animals - Cattle and Buffalo. $3^{\text {rd }}$ ed. Indian Council of Agricultural Research, New Delhi. p24.

8. AOAC. (2012) Official Methods of Analysis. 19 $9^{\text {th }}$ ed. Association of Official Analytical Chemists, Washington, DC. p1-77.

9. Van Soest, P.J., Robertson, J.B. and Lewis, B.A. (1991) Methods for dietary fibre, neutral detergent fibre and non starch polysaccharides in relation to animal nutrition.
J. Dairy Sci., 74: 3583-3597.

10. Snedecor, G.W. and Cochran, W.G. (1994) Statistical Methods. $8^{\text {th }}$ ed. The Iowa State University Press, Ames, IA. p314.

11. SPSS. (2012) Statistical Product and Service Solutions (SPSS) Version 21.0. IBM, SPSS Inc., USA.

12. Duncan, D.B. (1955) Multiple range and F-test. Biometrics, 11: $1-42$.

13. Ally, K. (2003) Influence of Level and Degradability of Dietary Protein on Early Lactation in Cross Bred Cows. $\mathrm{PhD}$ Thesis. Kerala Agricultural University, Mannuthy. p145.

14. Mohan, S.K.M. (2003) Assessment of the Dietary Level of Minerals for Lactation in Crossbred Cows in Kerala Under Different Feeding Systems. PhD Thesis. Kerala Agricultural University, Mannuthy. p130.

15. Mondal, M.K. and Paul, S.K. (2012) Haemato-biochemical profile in repeat breeding cross-bred cows. Explor. Anim. Med. Res., 2(1): 60-65.

16. Delahoy, J.E., Muller, L.D., Bargo, F., Cassidy, T.W. and Holden, L.A. (2003) Supplemental carbohydrate sources for lactating dairy cows on pasture. J. Dairy Sci., 86(3): 906-991.

17. Hundal, J.S., Gupta, R.P., Wadhwa, M. and Bakshi, M.P.S. (2004) Effect of feeding total mixed ration on the productive performance of dairy cattle. Anim. Nutr. Feed Technol., 4: $179-186$

18. Shiraz, K., Thangavel, A. and Selvasubramaniyan, S. (2010) Blood biochemical profile in repeat breeding cows. Tamil Nadu J. Vet. Anim. Sci., 6(2): 75-80.

19. Shakkarpude, J., Deepika, D.C., Singh, H.S., Mishra, A. and Caesar, N.K. (2013) Inter-relationship of certain biochemical parameters of physiological significance with reproductive pattern in crossbred cows. Res. J. Vet. Pract., 1(1): 12-13.

20. Kim, S.H., Alam, M.J., Gu, M.J., Park, K.W., Jeon, C.O., Ha, J.K., Cho, K.K. and Lee, S.S. (2012) Effect of total mixed ration with fermented feed on ruminal in vitro fermentation, growth performance and blood characteristics of Hanwoo steers. Asian Aust. J. Anim. Sci., 25(2): 213-223.

21. Pina, D.S., Filho, V.S.C., Valadares, R.F.D., Detmann, E., Campos, J.M.S., Fonseca, M.A., Teixeira, R.M.A. and Oliveira, A.S.O. (2006) Estimation of microbial protein synthesis and urea metabolism in lactating dairy cows fed diets supplemented with different protein sources. Rev. Bras. Zootec., 35(7): 1551-1559.

22. Raghuvansi, S.K.S., Tripathi, M.K., Misra, A.S., Chaturvedi, O.H., Prasad, R., Saraswat, B.L. and Jakhmola, R.C. (2007) Feed digestion, rumen fermentation and blood biochemical constituents in Malpura rams fed a complete feed-block diet with the inclusion of tree leaves. Small Rumin. Res., 71: 21-30.

23. Cozzi, G., Ravarotto, L., Gottardo, F., Stefani, A.L., Contiero, B., Moro, L., Brscic, M. and Dalvit, B. (2010) Reference values for blood parameters in Holstein dairy cows: Effects of parity, stage of lactation, and season of production. J. Dairy Sci., 94(8): 3895-3901.

24. Dominic, G. (2013) Effect of High Energy Diet on Early Lactation in Cross-Bred Cows. M.V.Sc. Thesis. Kerala Veterinary and Animal Sciences University, Pookode. p95.

25. Jacob, S.K. (2000) Assessment of Mineral Status During Pregnancy in Crossbred Cattle. M.V.Sc. Thesis. Kerala Agricultural University, Thrissur. p63.

26. Wadhwa, M., Kaushal, S., Bakshi, M.P.S. and Parmar, O.S. (2005) Assessment of nutritional status of lactating crossbred cows. Indian J. Anim. Nutr., 22(3): 144-151. 